\title{
Students' Satisfaction in Their Financial Support and Persistence in School
}

\author{
Jerald C. Moneva \\ Department of Education-Mandaue City Division \\ Mandaue City, Cebu, Philippines \\ Tel: +63908-927-3038Ｅ-mail: Freezingfire1979@gmail.com
}

Carl M. Jakosalem

Jagobiao National High School

Jagobiao, Mandaue City, Cebu, Philippines

Tel: +63927-640-5269Ｅ-mail: Carljakosalem64.0@gmail.com

\author{
Marsha H. Malbas \\ University of Visayas \\ Mandaue City, Cebu, Philippines
}

Received: February 5, 2020 Accepted: March 25, 2020 Published: April 2, 2020

doi:10.5296/ijssr.v8i2.16784 URL: http://dx.doi.org/10.5296/ijssr.v8i2.16784

\begin{abstract}
Financial satisfaction is a state in which students satisfied and contented to the financial support given by their parents. Students' persistence is the capability of students to continue in their studies even though they know that it would be difficult. The study intends to assess the level of students' satisfaction in financial support and their students' persistence in studies. The study used the descriptive correlational research design. The researcher used rating scale as a medium to obtain and gathered data needed. The tool is a researcher-made tool which consists of two parts which part A that tries to determine the Students' Satisfaction in financial support and part B which will determine the Students Persistence in Studies. The respondents of the study were chosen from Grade 11 and Grade 12 students of Jagobiao National High School with a total population of 235 students. The results of the study
\end{abstract}




\section{Macrothink}

International Journal of Social Science Research

ISSN 2327-5510 2020, Vol. 8, No. 2

revealed that in table 1 , students have a high level of satisfaction in financial support. Students who have enough financial support from their parents can feel satisfied. In table 2, students' persistence in studies depends on the financial support given by their parents. Students persist more if they have enough financial aid support and they also produces presentable works and excellent output and pass it on time or ahead of time. The study also reveals that there is a correlation between students' satisfaction in financial support and students' persistence in studies as the null hypothesis was rejected.

Keywords: Financial Satisfaction, Students' Persistence, Academic Achievement 


\section{Rationale}

Financial satisfaction is a state in which students satisfied and contented to the financial support that their parents had given to them. Satisfaction is the quality of fulfillment or contentment of a person's need or wants obtained. Satisfaction is the happy pleased feeling because of something; the act of providing what is needed or desired. Students' persistence is the capability of students to continue in their studies even though they know that it would be difficult and long road ahead. Persistence is the quality that allows someone to continue doing or trying to do something even though it is difficult (Merriam Webster Dictionary).

In relation to this, the researcher intends to know of how student's financial support affect students' persistence and determined to go to school. Satisfaction in students' financial support may motivate students to be persistent in their studies and have a better academic performance.

Through parental provision in financial support, students can produce presentable work and often submitting their outputs ahead of time. The performance of students in school may often depend on the socioeconomic background of their parents. Parental income level helps the students to buy the materials they need and it can also help them in supporting their children in school. Students' achievement rate in Jagobiao National high school is increasing for it depends on how their parents got involve in their studies. Students may intend to be motivated in their studies if they are well supported. Satisfaction of students in parent financial support is one of the factor that students may attain higher academic achievement. Parental financial availability can be a helpful tool for their children's achievement in school.

Financial has the important role in students' persistence decision. Satisfaction is a form of someone's effort in doing what they wanted to do to achieve their happiness. Financial satisfaction is how people manage their finances to the things they desired in order to meet their financial needs (Arifin, 2018). Furthermore, financial aid availability can impact on students' persistence in studies in order to perform well academically at school (Lin, 2016).

Financial satisfaction of students impact on student's performance and their persistence in school and their studies. Students could be determined and go to school with enthusiasm and overwhelmed. Students that have a full support from their parents might bring great success on the students. The researcher intends to assess the level of students' satisfaction in financial support and the students' persistence in their studies.

\subsection{Theoretical Background}

The study is supported by "Student Integration Model" of Vincent Tinto in 1975. He states that Student Integration Model defines as affecting persistence decision. The model presumes that the cognitive component consisting of the students' achievement exerts a direct effect on persistence decision (Cabrera, Alberto; Cabrera, Castaneda, 1992; Cabrera, Stampen, 1990).

The Student Integration Model signifies that finances are important in shaping student educational goals. It also indicates that finances can impact on student persistence in their studies. The model also hypothesizes that finances can affect the student social experiences at 
the institutions. According to the model, it indicates that persistence can be associated between student motivation, academic ability and social experiences. Student Integration Model is significant most especially in exploring the finances in persistence decision (Cabrera, Alberto; Cabrera, Castaneda, 1992; Cabrera, Stampen, 1990).

Indeed, financial has a direct significant to student's persistence. Students that have a full support from their parents have a great possibility that they will have a better academic performance in school. They will be more active in performing school activities and possibly they will be more punctual in submitting paper works, outputs and projects for they have enough financial support from their parents.

\subsection{Statement of Purpose}

The study intends to assess the level of satisfaction of the students in their financial support, extent of persistence of students in their studies and the correlation if any.

\subsection{Review of Related Literature}

Parental socioeconomic background might provide sufficient support about the needs of their children. Also, parental support can assist and encouraged their children to be involved in academic activities that can enhance more in their children's academic performance (Henrietta \& Odozi, 2014). Level of parental income impacts the academic achievement of the students. Additionally, the provision of parents in moral, financial and material support can encourage the students to perform academically in school (Machebe, Ezegbe, \& Onuoha, 2017). Students' who has low socioeconomic status may have lower academics than those who have higher income level (Walpole, 2003). Students' that has a low socioeconomic status may have lower academic achievement compared to the students who have a higher socioeconomic status. Parental socioeconomic status can enhance more on their children's academic achievement (Suleman, Aslam, Hussain, Shakir, \& Nisa, 2012). Family support enables the child to establish a better academic status (Chohan, 2010). Students who belong to stable socioeconomic status of a family will impact on their academic performances in school (Saifi \& Mehmood, 2011). The affordability of student economic background can help them in enhancing their academic performances (Okioga, 2013). Parental involvement of their children's studies whether financially or morally support can impact on the academic achievement of their children (Jeynes, 2007). The students can perform well academically especially when their parents were engaged and supported them compared to those who are not supported by their parents (Shahzad, Abdullah, Fatima, Riaz, \& Mehmood, n.d). Receiving support from parents either financially, morally or materials needed of students' absolutely enhanced the students' ability to complete on their studies (Astin, 1975). The family income was considered as a strong factor of socioeconomic status that affects the students' achievement (Akhtar, 2012). Students from high socioeconomic background can often perform well academically than those who are in a low socioeconomic status (Asiegbu \& Ezeugbor, 2018). The dominant factor of financial stability is a habit of saving. Individuals will have financial satisfaction if they will know how to manage their finances (Arifin, 2018). The amount of socioeconomic status of a family may often depend on their capability to save (Zainal, Kamaruddin, \& Nathan, 2019). Students' financial aid availability, academic 
performance as well as parental support were included as important influences toward students' completion (Lin, 2016).

Providing sufficient support can assist the students to persist in their studies (Haynes, 2008). Establishing learning communities that can be useful in teaching and tutoring students can help them in building persistence and can contribute in achieving their desired goals (Graham, Frederick, Winston, Hunter, \& Handelsman, 2016). Financial matters are the primary support that a student need in order to become persistent in their studies (Vanthournout, Coertjens, Gijbels, \& Donche, 2012). Family economic background are expected to influence the students to exert more on academics which can lead them to persist (Ethington, 1990). The increase of students' persistence may depend on the level of financial status that they belong (Voorhees, 1985). Financial assistance is relevant to the students' decision either to persist or not. In other words, students' who received sufficient financial aid can more likely to persist in studies than those who received lack of aid (Terkla, 1984). Families with lower socioeconomic status may lack of financial aid availability and educational support to their children's readiness at school. Therefore, the students' academic persistence will rely if their family has better income level to support (Memon, Joubish, \& Khurram, 2010). Students' achievement and academic integration could be a factor that lead to persistence (Lichtenstein, 2002). Academic and social activities are the factors that can contribute to students' persistence (Barbatis, 2010). Students' financial aid becomes increasingly important on persistence (Stewart, Lim, \& Kim, 2015). Students' socioeconomic status displayed increasing association with persistence (Cabrera, Hansen, \& Stampen, 1990). Indeed, income levels, financial aid packages interact as predictors on students' persistence. Thus, financial aid and the level of income play a vital role in persistence (Mendoza, Mendez, \& Malcolm, 2009). Financial aid availability has a total significant effect on students' persistence. Financial aid play a role to students for it helps to facilitate the accomplishments and participation of students in activities that leads to a better academic achievement (Cabrera, Nora, \& Castaneda, 1992). Students with Family of high level of income are more persevere to achieve better in school than those with low income family (Somers, 1995). Educating parents to be supportive on their child's studies can promote students persistence. Specifically, parents can enhance and encourage their children to persist and still be competent at school (Ratelle, Larose, Guay, Senecal, \& Laval, 2005).

\section{Research Method}

\subsection{Design}

The study used the descriptive correlational Research design. The study considered correlation between students' satisfaction in financial support and persistence in studies.

\subsection{Environment}

The study was conducted at Jagobiao National High School, Senior High School Department. Jagobiao National High School is located at North road Jagobiao, Mandaue City. The school has different facilities that enhance the abilities of the students. It has Science Laboratory, Computer Laboratory, Chorale Facility, Clinic and Library. The school offers academic 


\section{Macrothink}

strands namely: Accountancy and Business Management (ABM), General Academic Strand (GAS), Humanities and Social Sciences (HUMSS), Science, technology, engineering and Mathematics (STEM) and Technical Vocational Livelihood (TVL).

\subsection{Respondents}

The respondents of the study were from Grade 11 and Grade 12 students of Jagobiao National High School. It has total population of 152 female students and 83 from male students of Jagobiao National High School. All in all, there were 235 respondents from Grade 11 and Grade 12 students.

\subsection{Instruments}

The study used rating scale as a medium to obtain and gathered data needed. This tool is a researcher made tool that has two parts consisting of Part A: Students' Satisfaction in Financial Support and Part B: Students Persistence in their Studies. Part A has 10 indicators in determining the students' satisfaction in regards with financial support while Part B has 10 indicators in determining the Students Persistence in their studies. The instrument has 5 sections that will be used in rating the indicators. 5 as Strongly Agree, 4 as Agree, 3 as Neutral, 2 as Disagree and 1 as Strongly Disagree.

\subsection{Data Gathering Procedures}

The researcher gave a letter of approval to the School Head and asked a permission to conduct the study among Senior High School students to gathered data. The respondents will be guided by the rating scale and its indicators. The data will depend on the answers of the respondents. The gathered data will be used to process the whole study.

\subsection{Statistical Treatment}

The researcher used the weighted mean and chi-square in treating the data. The statistical tool will used to determine if there is any correlation between satisfaction of students in their financial support and the level of students' persistence in their studies. 


\subsection{Data Analysis and Discussion}

Table 1. Students' Satisfaction in Financial Support

\begin{tabular}{lll}
\hline INDICATORS & Weighted mean & Interpretation \\
\hline I am satisfied with my daily allowance. & 3.81 & Agree \\
My parents gave me extra money for my personal needs. & 3.45 & Agree \\
I can buy whatever I like such as school supplies in school. & 3.33 & Neutral \\
I am able to save a lot of money from the excess of my daily & 3.34 & Neutral \\
allowance. & & Neutral \\
I do not need to borrow money from my classmates. & 3.18 & Neutral \\
I save money to produce a presentable output. & 3.38 & Agree \\
I am able to save my extra allowance in order to buy the things & 3.43 & Agree \\
that I want. & & Neutral \\
I spend my money to the things that I prioritized the most. & 3.79 & 3.14 \\
I am able to buy personal belongings such as clothes, shoes or & & Neutral \\
jeans with my extra allowance. & & Agree \\
I enjoy consuming my allowance to the things that I desired. & 3.39 & $\mathbf{3 . 4 2}$ \\
OVERALL WEIGHTED MEAN & & \\
\hline
\end{tabular}

LEGEND: $\quad 5$ - Strongly Agree 4 - Agree 3 - Neutral 2 - Disagree 1 - Strongly Disagree

The table 1 above presents the three highest and lowest weighted mean. The first highest weighted mean is 3.81 which indicate that students are satisfied with their daily allowance. The second highest weighted mean is 3.79 which is indicator 8 that signifies that students spent their money to the things that they prioritized the most while the last highest weighted mean was 3.45 with the indicator "My parents gave me extra money for my personal needs". Parental involvement to their children can help them in buying the materials needed to their school and in order to attain better academic status (Jeynes, 2007). The three lowest weighted mean was interpreted as Neutral. The first lowest weighted mean was 3.14 with the indicator "I am able to buy personal belongings such as clothes, shoes or jeans with my extra allowance". The second lowest weighted mean was 3.18 with the indicator "I do not need to borrow money from my classmates". The last lowest weighted mean was 3.33 with the indicator "I can buy whatever I like such as school supplies in school". Parental socio economic background might provide sufficient support about the needs of their children (Henrietta \& Odozi, 2014). 


\section{Macrothink \\ International Journal of Social Science Research \\ ISSN 2327-5510 \\ 2020, Vol. 8, No. 2}

Table 2. Students Persistence in Studies

\begin{tabular}{lll}
\hline INDICATORS & Weighted mean & Interpretation \\
\hline $\begin{array}{l}\text { I actively participate in the discussions and answering exercises } \\
\text { even though I got a wrong answer. }\end{array}$ & 3.34 & Neutral \\
$\begin{array}{l}\text { I bother to ask the teacher if I do not understand the lessons or } \\
\text { discussions. }\end{array}$ & 3.28 & Neutral \\
$\begin{array}{l}\text { I exert more effort when I do difficult assignments. } \\
\text { I do searching (Google, Dictionary) when I hardly understand the } \\
\text { lessons. }\end{array}$ & 3.57 & $\begin{array}{l}\text { Agree } \\
\text { Agree }\end{array}$ \\
$\begin{array}{l}\text { I still persevere to do my outputs in the middle of the night just to } \\
\text { have a presentable output. }\end{array}$ & 3.51 & Agree \\
$\begin{array}{l}\text { I attend classes regularly. } \\
\text { I tried to attend the class even though I'm sick. }\end{array}$ & 4.18 & $\begin{array}{l}\text { Agree } \\
\text { I do given task even though I am not really good to the certain } \\
\text { subject. }\end{array}$ \\
$\begin{array}{l}\text { I tried to achieve a high score on quizzes, test and exams even I am } \\
\text { not good to the certain subjects. }\end{array}$ & 3.9 .81 & Agree \\
$\begin{array}{l}\text { Whenever I failed a subject, I do my best to recover it on the } \\
\text { second time. }\end{array}$ & 4.11 & Agree \\
OVERALL WEIGHTED MEAN & & Agree \\
\hline
\end{tabular}

LEGEND: $\quad 5$ - Strongly Agree 4 - Agree $\mathbf{3}$ - Neutral 2 - Disagree 1 - Strongly Disagree

The table 2 revealed the three highest and lowest weighted mean. The first highest weighted mean was 4.18 with the indicator "I attend classes regularly". Establishing learning communities can be useful in teaching students and can help them to persist in their studies and in achieving their desired goals (Graham, Frederick, Winston, Hunter, \& Handelsman, 2016). Followed by, 4.11 with the indicator "Whenever I failed a subject, I do my best to recover it on the second time". The last highest weighted mean was 4.01 with the indicator "I do searching (Google, Dictionary) when I hardly understand the lessons". The three lowest weighted mean was interpreted as Neutral and Agree. The first one was 3.28 with the indicator "I bother to ask the teacher if I do not understand the lessons or discussions" and followed by 3.34 with the indicator "I actively participate in the discussions and answering exercises even though I got a wrong answer". Providing sufficient support can assist the students to persist and participate in their studies well academically (Haynes, 2008). The last lowest weighted mean was 3.51 with the indicator "I still persevere to do my outputs in the middle of the night just to have a presentable output". 


\section{MInstitute ${ }_{\text {Mnk }}^{\text {Macrothin }}$}

International Journal of Social Science Research

ISSN 2327-5510

2020, Vol. 8, No. 2

Table 3. Cross Tabulation Between Students' Satisfaction In Financial Support And Students Persistence In Studies

\begin{tabular}{llll}
\hline & Value & df & Asymp. Sig. (2-sided) \\
\hline Pearson Chi-Square & $8.512 \mathrm{E}^{\mathrm{a}}$ & 675 & .000 \\
N of Valid Cases & 230 & & \\
\hline
\end{tabular}

a. 728 cells $(100.0 \%)$ have expected count less than 5 . The minimum expected count is .00 .

The P value (.000) is less than the alpha value (.05). The null hypothesis is rejected and the table 3 shows that there is a correlation between students' satisfaction in financial support and students' persistence in studies. Students' Satisfaction in financial support influence to students' persistence in studies. The family income was considered as a strong factor of socioeconomic status that affects the students' achievement (Akhtar, 2012). Level of parental income impact the academic achievement of the students. Additionally, the provision of parents in moral, financial and material support can encouraged the students to perform academically in school (Machebe, Ezegbe, \& Onuoha, 2017).

\section{Findings}

From the study being conducted, the researcher found out that the students from Jagobiao National High School has a high level of satisfaction in financial support given by their parents. It was found out that students are satisfied with their daily allowance and they are able to save a lot of money from the excess of their allowance and spent it to the things that they want.

Students' level of persistence relies on the amount of financial support of parents to their children. It showed that students are actively participated in performance tasks and answering exercises even they got a wrong answer. Students persist to learned the certain subjects even they feel it difficult and able to produce a presentable outputs through the financial support by their parents as it helps them to buy the materials needed in order to achieve a better academic achievement and performance.

There is any correlation between students' satisfaction in financial support and students' persistence in studies. The study revealed that students were able to perform academically in school if the support given to them is enough to their needs. The parent's provision in dealing the needs of their children plays a vital role in their children's academic outcomes. Students' are trying to persist in their studies and able to produce an excellent works if they have enough financial support from their parents.

\section{Conclusion}

Students who have enough financial support can be a persister in school. Students who are satisfied to the support from their parents may tend to perform well academically at school. Also, they can achieve a higher academic achievement than to the students who have a lower support. Students' could also produce an excellent output in the certain subjects because 
finances can help them buy to the things that they need such as materials, and other things to prepare in order to create a presentable work. Additionally, the researcher concluded that support of the parents could be a big help for the children to improve in their academic performance and a great opportunity for the students to exert more effort in their academics.

\section{Recommendation}

Students must be persistent in doing academic task and outputs and do all the tasks given. They must continue in their studies if they are well supported by their parents. They must not waste the time and they must always remember to be grateful enough to their parents.

Parents should continue to provide a sufficient support to their children to help them in building their children's persistence in studies. Parents must also continue to be involved in their children's studies so that they will be able to know on where to assess and how to help their children to achieve a better outcome in their academics.

Teachers must help and teach their students to perform well academically in school. They must be a guidance of the students in assessing their academics on where to develop and need to be assessed.

\section{References}

Akhtar, Z. (2012). Socio-economic status factors effecting the students' achievement: A predictive study. International Journal of Social Sciences and Education, 2(1), 281-287. Retrieved from https://www.ijsse.com/sites/default/files/issues/2012/volume $\% 202 \% 20$ issue $\% 201 \% 20 \mathrm{Jan} \% 2$ 02012/paper\%2021/paper-21.pdff

Arifin, A. Z. (2018). Influence factors toward financial satisfaction with financial behavior as intervening variable on Jakarta area workforce. European Research Studies Journal, 11(1), 90-103. https://doi.org/10.35808/ersj/932

Asiegbu, C. E., \& Ezeugbor, C. O. (2018). Relationship between the socio-economic status of parents and academic performance of students in onitsha north local government area of Anambra state. Journal Plus Education, 19(1), 166-175. https://doi.org/10.24250/jpe/1/2018/CEA/COE

Astin, A. W. (1975). Financial aid and student persistence, 26. Retrieved from https://files.eric.ed.gov/fulltext/ED112804.pdf

Barbatis, P. (2010). Underprepared, ethnically diverse community college students: Factors contributing to persistence. Journal of Developmental Education, 16-26. Retrieved from https://scholar.google.com/scholar?hl=en\&as_sdt=0\%2C5\&q=underprepared $\% 2 \mathrm{C}+$ ethnically + diverse + community $7 \mathrm{btnG}=\# \mathrm{~d}=\mathrm{gs} \_\mathrm{qabs} \& \mathrm{u}=\% 23 \mathrm{p} \% 3 \mathrm{DPV} 28 \mathrm{YnZ} \mathrm{d} 9 \mathrm{IYJ}$

Cabrera, A., \& Alberto, F. (1992). The role of finances in the persistence process: A structural model.

Retrieved from https://www.researchgate.net/publication/225935627_The_Role_of_Finances_in_the_Persiste nce_process_A_structural_model 
Cabrera, A. F., Hansen, L. W., \& Stampen, J. (1990). Exploring the effects of ability-to-pay on persistence in college. The Review of Higher Education, 13(3), 303-306. https://doi.org/10.1353/rhe.1990.0020

Cabrera, A. F., Nora, A., \& Castañeda, M. B. (1992). The role of finances in the persistence process: A structural model. Research in Higher Education, 33, 571-593. https://doi.org/10.1007/BF00973759

Cabrera, A. F., Nora, A., Castañeda, M., Nora, A., \& Hengstler, D. (1992). The convergence between two theories of college persistence. Journal of Higher Education. https://doi.org/10.2307/1982157

Cabrera, A., Stampen, J., \& Lee, H. (1990). Exploring the effects of ability to pay on persistence college. The Review of Higher Education, 13(3), 303-306. https://doi.org/10.1353/rhe.1990.0020

Chohan, B. I. (2010). Impact of parental support on the academic performance and self-concept of the student. Journal of Research and Reflections in Education, 4(1), 14-26. https://doi.org/10.1007/BF00992313

Ethington, C. A. (1990). A psychological model of student persistence. Research in Higher Education, 314(1), 14-26. https://doi.org/10.1126/science.1240487

Graham, M. J., Frederick, J., Winston, A. B., Hunter, A. B., \& Handelsman, J. (2016). Increasing persistence of college students in STEM. Science Education, 341, 1455-1457.

Haynes, M. R. (2008). The impact of financial aid on postsecondary persistence: A review of the literature. Journal of Student Financial Aid, 37(3), 29-35. Retrieved from https://ir.library.louisville.edu/cgiviewcontent.cgi?article=1047\&content-jsfa

Henrietta, M. C., \& Odozi, I. C. (2014). Influence of parental socio-economic status on academic achievement of students in selected schools in Nigeria: A case study of Enugu state. Journal of Education and Practice, 5(2), 105-110. Retrieved from https://pdfs.semantischolar.org/sites/default/files/issues/2011/v1i2/p3/paper.pdf

Jeynes, W. H. (2007). The relationship between parental involvement and urban secondary school student and academic achievement. Urban Education, 42(1), 82-110. https://doi.org/10.1177/0042085906293818

Lichtentein, M. (2002). The role of finances aid in hispanic first-time freshman persistence. AIR 2002 Forum Paper, 2-29. Retrieved from https://scholar.google.com/scholar?hl=en\&as_sdt=0\%2C5\&q=the+role+of + finances + aid + in + hispanic\&dbtnG=\#d=gs_qabs\&u=23p\%3DTIQXEEVvxMJ

Lin, C. H. (2016). Examining the effects of financial aid on student persistence in Taiwanese higher education. International Education Studies, 9(8), 36-50. https://doi.org/10.5539/ies.v9n8p36

Machebe, C. H., Ezegbe, B. N., \& Onuoha, J. (2017). The impact of parental level of income 
on students' academic performance in high school in Japan. Universal Journal of Educational Research, 5(9), 1614-1620. https://doi.org/10.13189/ujer.2017.050919

Memon, G. R., Joubish, M. F., \& Khurram, M. A. (2010). Impact of parental socio-economic status on students' educational achievement at secondary schools of district malir, Karachi. Middle-East Journal of Scientific Research, 6(6), 678-683. Retrieved from $\mathrm{https}: / /$ scholar.google.com/scholar?hl=en\&as_sdt=0\%2C5\&q=impact + of + parental + socio-eco nomic + status + onstudents + educational + achievement\&oq $=$ impact + of + parental + socio-econom $\mathrm{ic}+$ status + onstudents + educational + achiev $\# \mathrm{~d}=\mathrm{gs} \_q a b s \& \mathrm{u}=23 \mathrm{p} \% 3 \mathrm{DdqH} 6 \mathrm{ZKxbN} 1 \mathrm{~kJ}$

Mendoza, P., Mendez, J. P., \& Malcolm, Z. (2009). Financial aid and persistence in community colleges: Assessing the effectiveness of federal and state financial aid programs in Oklahoma. Mendez et al., 37(2), 112-135. https://doi.org/10.1177/0091552109348045

Okoiga, C. K. (2013). The impact of students' socio-economic background on academic performance in universities, a case of students in kisii university college. American International Journal of Social Sciences, 2(2), 38-46. Retrieved from https://www.aijssnet.com/journals/vol_2_No_2_March_2013_/5.pdf

Ratelle, C. F., Larose, S., Guay, F., Senecal, C., \& Laval, U. (2005). Perceptions of parental involvement and support as predictors of college students' persistence in a science curriculum. Journal of Family Psychology, 19(2), 286-293. https://doi.org/10.1037/0893-3200.19.2.286

Saifi, S., \& Mehmood, T. (2011). Effects of socioeconomic status on students' achievement. International Journal of Social Sciences and Education, 1(2), 119-128. Retrieved from https://www.ijsse.com/sites/default/files/issues/2011/v1i2/p3/paper.pdf

Shahzad, M., Abdullah, F., Fatima, S., Riaz, F., \& Mehmood, S. (n.d.). Impacts of parental support on academic performance among secondary school students in Islamabad. The Explorer Islamabad: Journal of Social Sciences, 1(7), 228-231. Retrieved from https://s3.amazonaws.com/academia.edu.documents/38355168/EJSS50IMPACTSOFPAREN TALSUPPORTONACADEMICPERFORMANCEAMONGSECONDARYSCHOOLSTUDE NTSINISLAMABAD.pdf

Somers, P. (1995). A comprehensive model for examining the impact of financial aid on enrollment and persistence. Journal of Student Financial Aid, 25(1), 12-27. Retrieved from htpps://ir.library.louisville.edu/cgi/viewcontent.cgi?article=1133\&context=jsf

Stewart, S., Lim, D. H., \& Kim, J. (2015). Factors influencing college persistence for first-time students. Journal of Developmental Education, 38(3), 12-20. Retrieved from htpps://files.eric.ed.gov/fulltext/EJ1092649.pdf

Suleman, Q., Aslam, H. D., Hussain, I., Shakir, M., \& Nisa, Z. U., (2012). Effects of parental socioeconomic status on the academic achievement of secondary school students in district karak (Pakistan). International Journal of Human Resources Studies, 2(4), 14-32. https://doi.org/10.5296/ijhrs.v2i4.2511

Terkla, D. G. (1984). Does financial aid enhance undergraduate persistence? 1-17. Retrieved 
from https://files.eric.ed.gov/fulltext/ED253127.pdf

Vanthournout, G., Coertjens, L., Gijbels, D., \& Donche, V. (2012). Students' persistence and academic success in a first-year professional bachelor program: The influence of students' learning strategies and academic motivation. Education Research International, 1-10. https://doi.org/10.1155/2012/152747

Voorhees, R. A. (1985). Financial aid and persistence: Do the federal campus-based aid programs make a difference? Journal of Student Financial Aid, 15(1), 20-30. Retrieved from https://ir.library.louisville.edu/cgi/viewcontent.cgi?article1419\&context=jsfa

Walpole, M. B. (2003). Socioeconomic status and college: How SES affect college experiences and outcomes. The Review of Higher Education, 27(1), 45-73. https://doi.org/10.1353/rhe.2003.0044

Zainal, N. R., Kamaruddin, R., \& Nathan, S. B. S. (2009). Socio-economic status and parental savings for higher education among malaysian bumiputera families. International Journal of Economics and Finance, 1(2), 170-173. https://doi.org/10.5539/ijef.v1n2p170

\section{Glossary}

Students' Satisfaction in Financial Support: is the students' contentment or satisfied about the financial support that their parents had given to them. It is a feeling of satisfied in achieving the desires or wants of students with the help of financial support given by their parents.

Students Persistence in Studies: is the students' capability to continue in their study even though it is difficult. It is the students' capability to engage in some difficulty yet, enduring for the desired goals.

\section{Appendix}

Survey Questionnaire for the Satisfaction of Students in Financial Support and Persistence in school

Instruction: This tool is a researcher made tool which intends to determine the level of satisfaction of students in financial support in Part A and the level of students' persistence of students in Part B. The data gathered will be treated confidentially.

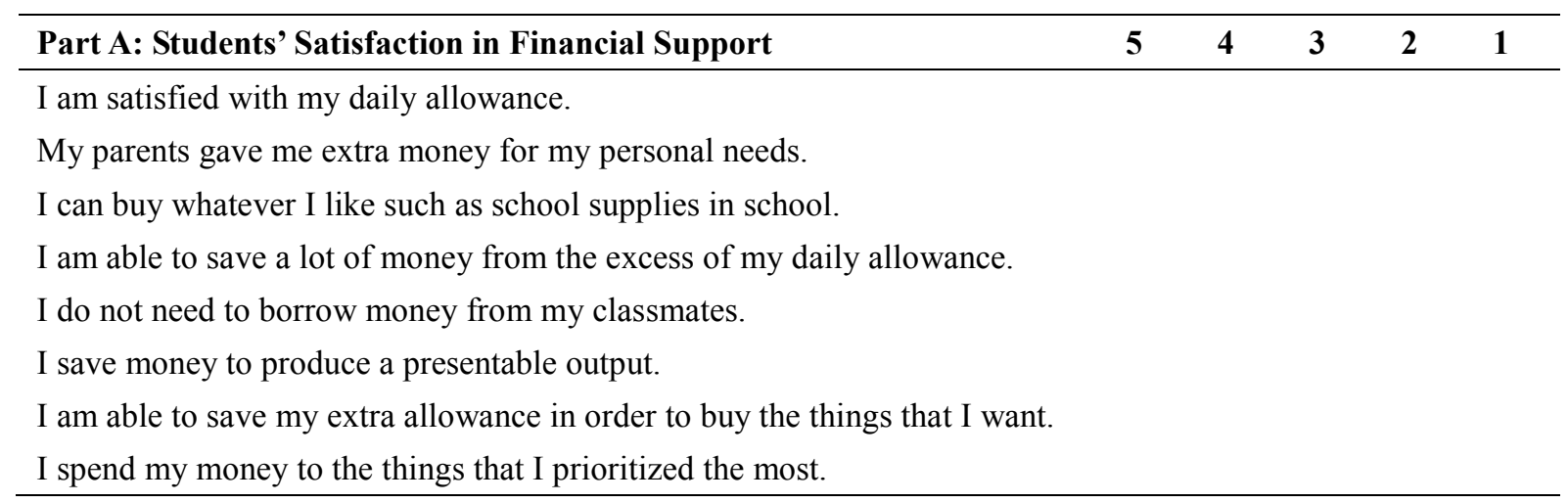


I am able to buy personal belongings such as clothes, shoes or jeans with my extra allowance.

I enjoy consuming my allowance to the things that I desired.

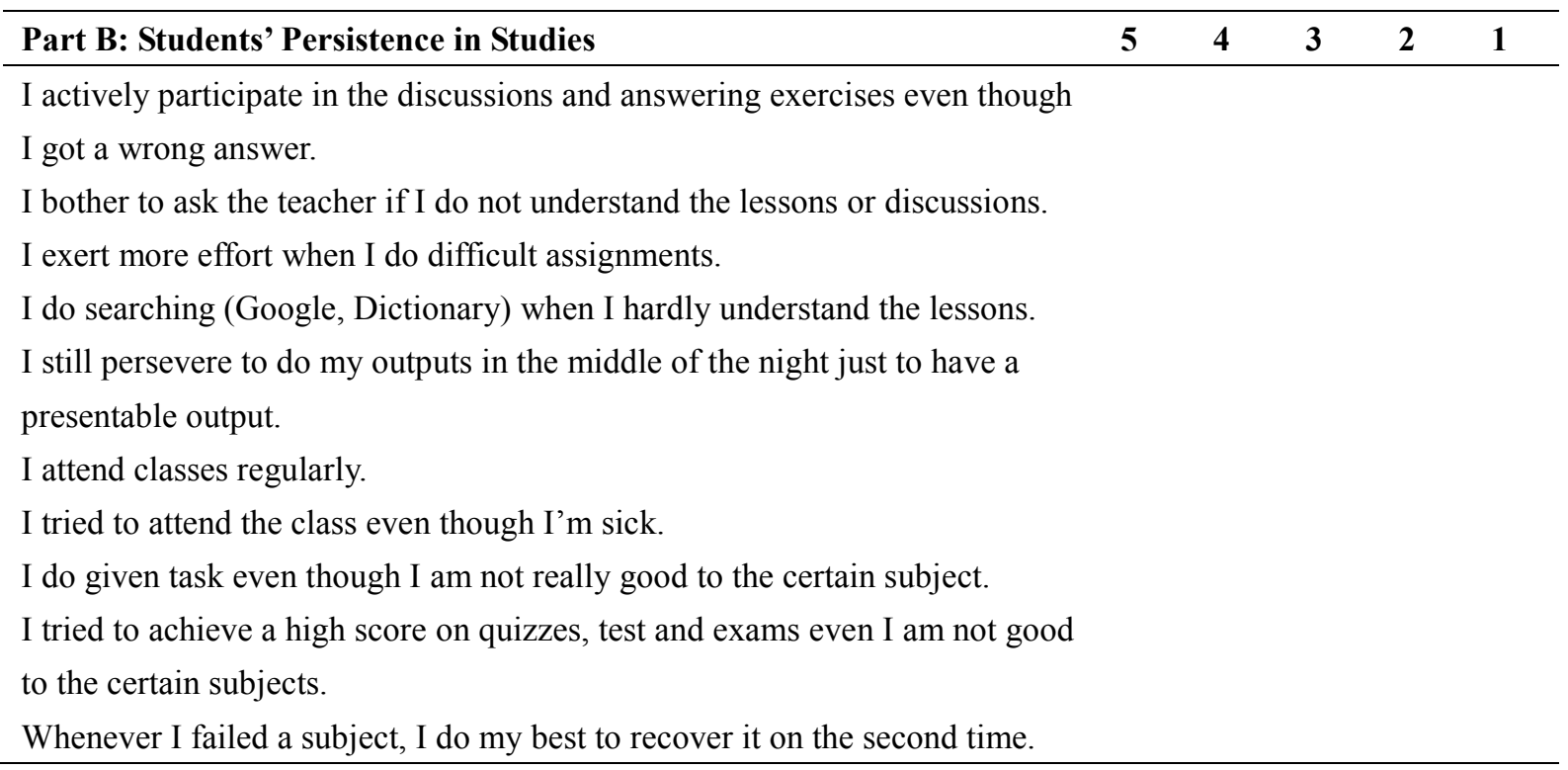

\section{Copyrights}

Copyright for this article is retained by the author(s), with first publication rights granted to the journal.

This is an open-access article distributed under the terms and conditions of the Creative Commons Attribution license (http://creativecommons.org/licenses/by/4.0/). 